\title{
A PASSZÍV SPORTFOGYASZTÁS KOMPLEX ELEMZÉSE
}

\author{
Balogh Renátó - Bácsné Bába Éva
}

\begin{abstract}
Absztrakt: Az alacsony fogyasztói érdeklődés a magyar klubok üzleti alapú müködésének egyik legfőbb gátja, éppen ezért a passzív sportfogyasztás vizsgálata felettébb szükségszerü a magyar labdarúgásban. Kutatásunkban a passzív sportfogyasztás komplex elemzését végeztük el, amely a szurkolókra és a mérkőzésektől távolmaradókra egyaránt kiterjedt. Vizsgálati módszerünk a szurkolók esetében szurkolói motivációs skála, míg a távolmaradók esetében sportfogyasztástól való tartózkodási skála volt. A skálák megbízhatóságát Cronbach-alfa érték számítással teszteltük, melynek eredménye a legtöbb faktor esetében meghaladta az elvárt küszöbértéket. Kutatási eredményeink cáfolják azt a közvélekedést, hogy a sikertelenség központi szerepet játszik az alacsony nézői érdeklődésben. Vizsgálatunk során arra a következtetésre jutottunk, hogy a szurkolókat, nézőket a siker helyett, inkább az olyan szocio-kulturális tényezők csalogatják ki a stadionokba, mint a csapattal való azonosulás és ahhoz való lojalitás.
\end{abstract}

Abstract: One of the main obstacles of the business-based operation of Hungarian football clubs is low consumer interest. Because of this reason the examination of passive sports consumption in Hungarian football is very necessary. In our research, we conducted a complex analysis of passive sports consumption, including both the fans and those absent from the stands. For the latter a scale measuring absence from sport consumption and for the fans a "fan motivation scale" was used. The reliability of the scales was tested by Cronbach's alpha calculation, which resulted in exceeding the expected threshold for most factors. Our research results refute the notion that failure plays a central role in low viewer interest. Our study concludes that socio-cultural factors, such as identifying with and loyal to the team, tend to attract fans, spectators rather than success.

Kulcsszavak: sportmarketing, fogyasztói magatartás, sportfogyasztás

Keywords: sportmarketing, consumer behaviour, sport consumption

\section{Bevezetés}

A labdarúgás az elmúlt évtizedekben mindinkább a szórakoztatóipar szerves részévé vált, évente többmilliárd eurós bevételt generáló üzletág. Nyugat-Európában a szurkolók kedvenc csapatuk mezét, sálját és más termékeit viselve, hétről-hétre megtöltik a stadionok lelátóit, a hirdetési felületeken multinacionális vállalatok logóival és üzeneteivel találkozhatunk, a mérkőzéseket pedig - kis túlzással - a Föld bármelyik pontján követhetjük televízión keresztül. Európában a labdarúgás az egyetlen olyan szórakoztatóipari termék, mely képes hosszú éveken keresztül, kéthetente több tízezres stadionokat fogyasztókkal megtölteni, ugyanis más szórakoztatóipari szereplők - például zenekarok - „vándorcirkuszként” müködnek. A látványsportok, különös tekintettel a futballra, magukban hordozzák azt az értéket, amely felkelti a fogyasztók érdeklődését és ami még fontosabb, képesek fenntartani is azt, hiszen a mérkőzések egyszerre rendelkeznek a szórakoztatóipari termékekkel szemben támasztott show-, illetve informális elemekkel, valamint a kimenet bizonytalansága garantálja a drámai faktort is.

Magyarországon és a környező országokban viszont a futball szektor az üzleti módszerek alkalmazásában elmarad a nyugati példáktól, amely komoly hatással van a labdarúgócsapatok müködésére is. Az 1990-es évektől kezdve egyre szembeötlőbb 
a különbség a nyugat- és a közép-európai klubok között úgy sportszakmai, mint sportgazdasági tekintetben.

Felmerül a kérdés, hogy az üzleti aspektus egyes részeinek hiánya, milyen okokra vezethető vissza. Fogyasztók nélkül nem beszélhetünk üzleti alapú sportról (András, 2003), így adódik a válasz, hogy az üzleti elem, elsősorban az „üres” stadionok miatt marad el Közép-Európában, ekképpen Magyarországon is.

Az átlagnézőszám adatok az elmúlt szezonokban annak ellenére sem növekedtek érdemben, hogy a kormány stadionépítési programjának köszönhetően 2014 óta számos futballklub kapott új otthont (1. ábra).

\section{1. ábra: NB1-es bajnoki mérkőzések átlagnézőszám adatai 2010/2011-2018/2019 között}



Forrás: worldfootball.net

Az az általános vélekedés, hogy az alacsony nézői érdeklődést a magyar klubés válogatott futball sikertelensége, valamint a mérkőzések alacsony színvonala magyarázza, azonban mi úgy gondoljuk - nem vitatva ezek jelentőségét -, hogy e jelenség mögött más tényezők is meghúzódhatnak. Kutatásunkban ezeket a tényezőket szeretnénk azonosítani.

\section{Szakirodalmi áttekintés}

A passzív sportfogyasztással kapcsolatos vizsgálatokat két nagy csoportba tudjuk sorolni aszerint, hogy a kutatók, hogyan tekintenek a sportfogyasztóra, racionálisan viselkedö fogyasztóként vagy irracionális magatartású nézőként, esetleg szurkolóként.

Azon kutatások, amelyek a klasszikus közgazdasági megközelítésből indulnak ki, miszerint a sportfogyasztó racionális, az alábbi tényezőkre helyezik a hangsúlyt:

- A néző jövedelmi helyzete

- Jegyárak

- A játék színvonala

- A csapat szereplése, sikeressége 
- A kimenet bizonytalansága

- A létesítmény

Ferguson et al. (1991) eredményei igazolták, hogy a nézö jövedelmi helyzete befolyásolja azon döntését, hogy kilátogat-e egy sporteseményre vagy sem. Erre a megállapításra szinte evidenciaként tekinthetünk.

A jegyárak esetében, azonban már nem ennyire egyértelmü az eredmény. Hansen-Gauthier (1989) arra a megállapításra jutottak, hogy a jegyárak hatást gyakorolhatnak a nézői érdeklődésre, ezzel szemben Dobson-Goddard (1995) angol csapatok körében végzett kutatásuk során azt a következtetést vonták le, hogy a szurkolók árérzékenysége csekélynek tekinthető. Madalozzo-Villar (2009) hasonló eredményre jutottak a brazil labdarúgás iránti kereslet esetében.

A magyar labdarúgó-mérkőzések alacsony nézőszám adatait leginkább a mérkőzések gyenge színvonalával magyarázzák. Való igaz, a témával foglalkozó kutatók befolyásoló faktorként azonosították, különböző elnevezéssel a sportteljesítmény színvonalát (Forrest-Simmons, 2002; Pawlowski-Nalbantis, 2015). Dénes (1998) megfogalmazásában ez a csapat teljesítményének minősége, amely szerint minél jobb játéktudással rendelkező labdarúgókat és csapatokat láthat a közönség, annál nagyobb lesz az érdeklődés, András (2004) ezt a tényezőt a sportteljesítmény minőségének nevezi. Kassay (2012) szerint Magyarországon az alapszolgáltatás (maga a mérkőzés) előállítása, valamint az elvárt és tapasztalt teljesítmény közötti különbség jelenti az alapproblémát. Dénes (1998) felhívja a figyelmet rá, hogy a nézői érdeklődésre igazából nem az abszolút teljesítmény gyakorol közvetlen hatást, hanem sokkal inkább a bizonytalan kimenet, amely relatív teljesítményként fogható fel, amelyet más kutatások is megerősítenek (Fort-Quirk, 2011; Lee-Fort, 2012; Kassay-Géczi, 2016). A bizonytalan kimenetel azt jelenti, hogy a mérkőzések végeredményét nem tudjuk elöre, izgalmas fordulatokkal tarkított az összecsapás, amelyet a szurkoló drámaként élhet meg. A bizonytalan kimenetelt, azonban nem csupán egy-egy mérkőzésre kell érteni, hanem egy bajnoki szezonra, egy ligára vagy más versenysorozatra is (Szymanski, 2003; Goossens, 2006; Cox, 2015; Sung-Mills, 2018).

A létesítmény és az ahhoz kapcsolódó kiegészítő szolgáltatások is jelentősen befolyásolhatják a fogyasztói érdeklődést. Erre a megállapításra jutott többek között (Rust-Oliver, 1994; Wakefield-Blodgett 1996, András, 2003; Clemens et al. 2011 Yoshida et al. 2013). Magyarországon a sportlétesítmények hosszú ideig kritikus állapotúak voltak, a rendszerváltás után elmaradtak a beruházások és a fejlesztések (Bács-Kozma 2018), de annak köszönhetően, hogy a 2010-es kormányváltás után a sport kiemelt stratégiai ágazattá vált (Stocker-Szabó, 2017), melynek keretében elindult a stadionépítési program, a sportinfrastruktúra jelentősen javult az elmúlt években.

A klasszikus közgazdasági megközelítés mellett, létezik egy „másik iskola”, amely a szocio-kulturális tényezőkre helyezi a hangsúlyt, melyek a következőek:

- Szabadidő-eltöltési szokások

- Közösséghez való tartozás

- Szórakozás, kikapcsolódás 
- Stadionban uralkodó hangulat

- Lojalitás

- Lokálpatriotizmus

- Média

- Sportszövetségi intézkedések

A labdarúgó-mérkőzések iránti alacsony nézői érdeklődés kapcsán az egyik legfontosabb tényezőt, a szabadidö-eltöltési szokásokat jellemzően figyelmen kívül hagyják, azonban számos kutatás felhívta a figyelmet ennek jelentőségére (FosterRobinson, 2010; Lera Lopez-Rapún 2011). A szabadidő-eltöltési szokások rövid idő alatt rendkívül sokat változtak az elmúlt évtizedben. A digitalizáció következtében a fiatalok egyre több időt töltenek a számítógépük elött, egyre több időt interneteznek, tehát életük egy része a virtuális térbe került (Székely-Szabó, 2017). Mindeközben nemcsak a passzív sportfogyasztás iránti kereslet, hanem a hagyományos kulturális intézmények, mint a színház, a mozi, a koncert vagy a múzeum látogatottsága is folyamatosan csökkenő tendenciát mutat, azonban meg kell jegyezni, hogy településtípus alapján jelentős eltéréseket fedezhetünk fel. 2000ben a budapesti fiatalok 11\%-a járt havi rendszerességgel színházba, ezzel szemben a községekben élők esetében ez az arány nem érte el az 5\%-ot sem. 2008-ra a budapesti fiatalok körében emelkedés mutatkozott, hiszen 13\%-uk havonta látogatott el színházba, ugyanakkor a községekben élőknél nem történt változás, ugyanúgy 5\% alatti volt. 2016-ra viszont jelentősen csökkent a fövárosban lakók esetében is a havonta színházba járók aránya, a 2008-as 13\%-ról 5\%-ra esett vissza, a falvakban élőknek pedig mindösszesen 2\%-ra jár havi rendszerességgel színházi előadásokra (Székely-Szabó, 2017).

A közösséghez való tartozás igénye természetes emberi vágy. Ez az igény tökéletesen kielégíthető egy sporteseményen való részvétel esetén, hiszen egy család tagjaivá válhatunk, nem véletlen, hogy a szurkolók „,harmadik otthonuknak” tekintik kedvenc csapatuk stadionját (Chelladurai, 1994).

A sporttal és sporteseményekkel szembeni egyik legfontosabb elvárás, hogy élményt nyújtson és szórakoztató jellegü legyen, melyet a sport területén megjelenő trendek is igazolnak (Müller, 2009; Müller et al., 2017; Gődény et al., 2018). Wafi et al. 2017 igazolta, hogy a sporteseményekre való látogatást az ismeretszerzés és a mindennapokból való menekülés motiválta, melyet az eseményszervezőknek figyelembe kell venni. Kassay (2018) szerint a magyar labdarúgásból ez az élménynyújtás hiányzik a leginkább, amelynek csak egyik szelete az alapszolgáltatás gyenge minősége. Nem sikerül olyan kiegészítő tartalmakkal megtölteni a labdarúgó-mérkőzéseket, hogy azok kéthetente ne csak a 90 perces összecsapásokról szóljanak.

Számos kutatás igazolta, hogy a stadionban uralkodó hangulat jelentősen befolyásolja a fogyasztói érdeklődést a sport területén (Hill-Green, 2000; UhrichKoenigstorfer, 2009; Chen et al., 2013). A jó hangulat hatással lehet a percepciónkra. Egy teltházas, hangos szurkolás közepette megrendezett mérkőzést hajlamosak vagyunk felül vagy túlértékelni, míg ennek az ellentettje is igaz. 
A sport, különösen a csapatsportok szurkolóira leginkább a lojalitás jellemző. Bühler (2005) szerint is a szurkolók irracionálisan viselkednek, tekintettel arra, hogy hüségesek maradnak kedvenc csapatukhoz az elért eredményektöl függetlenül. Sutton el al. (1997) az elkötelezettség mértéke szerint három szintet különböztetett meg a szurkolók esetében, az enyhén (social fan), a közepesen (focused fan) és az erősen (vested fan) elkötelezettet. A szerzők arra a megállapításra jutottak, hogy minél szorosabb a kapcsolat a szurkoló és a csapat között annál kevésbé fontos a klub teljesítménye. Az alacsony elkötelezettségi szinten a társas kapcsolatok, míg a magasabb szinten már a csapathoz való érzelmi elköteleződés válik hangsúlyossá.

Madarász (2018) szerint a sport a nemzeti identitás egyik meghatározó tényezője. A klubfutballra nézve ez a nemzeti identitás természetszerüleg kisebb területre szükül, régióra vagy még inkább városra, városrészre. A klublabdarúgás tradicionálisan egy várost képvisel, így ezek a klubok és szurkolóik lokális identitással rendelkeznek, a szimpatizánsok számára különös jelentőséggel bírnak a gyökerek (Ranc, 2012). Duke (2002) felhívja a figyelmet, hogy a hivatásos sportban egyre inkább teret nyer a globalitás, ugyanakkor nem lehet azt figyelmen kívül hagyni, hogy a labdarúgás hagyományosan a futballklub, a helyi közösségek és a szurkolók kapcsolatában gyökerezik.

Watson (2003) megállapította, hogy a média hozzájárulhat az elöítéletek megerősítéséhez és fontos kérdések triviálissá tételéhez. Ez azt jelenti, hogy ha valami elég sokszor hangzik el vagy jelenik meg, valamelyik médium felületén, akkor a hírfogyasztók előbb-utóbb elfogadják azt függetlenül annak igazságtartalmától. A média a szórakoztató funkciója mellett, szolgáltatja, szüri és formálja mindazon információkat, amelyekkel nap mint nap találkozunk életünk során (Giddens, 2008). A fiatalabb generáció tagjai jellemzően már nem saját tapasztalatból és élményből vonják le következtetéseiket a magyar labdarúgásról, sokkal inkább, valamilyen médium siet a segítségükre ebben. Földesiné et al. (2010) ennek kapcsán kiemelik, hogy a sportban folyamatosan találkozhatunk olyan negatív jelenségekkel vagy cselekedetekkel, amelyre a mindig szenzációt kereső média szívesen fókuszál annak érdekében, hogy olvasottságát, nézettségét emelje. Az Egyesült Államokban már az 1960-as években megjelentek olyan tényfeltárónak nevezhető újságcikkek, melyek a sportot és a sportolókat kívánták demisztifikálni. Balogh et al. (2019) arra a következtetésre jutott, hogy a média jelentősen befolyásolhatja a magyar labdarúgás iránti keresletet, tehát minél inkább negatív fényben tüntetik fel a médiumok a magyar futballt, annál kevésbé lesz az vonzó az emberek számára.

A sportági szakszövetség, hazánk esetében a Magyar Labdarúgó Szövetség (MLSZ), a bajnokság szervezésével, a különböző sportszakmai és -menedzsment szabályokkal hatással lehetnek a fogyasztói érdeklődésre (Balogh-Bácsné, 2019). Az MLSZ az elmúlt években számos olyan új szabályt, intézkedést vezetett be, amely a nézőszám emelkedését volt hivatott elérni. Balogh-Bácsné (2019) kutatásából kiderül, hogy ezt a célt az intézkedések jelentős többsége nem tudta elérni, azok inkább kontraproduktívak voltak. Ilyen volt a kötelező szurkolói kártya bevezetése, amely intézkedés regisztrációhoz és személyes adatok megadásához 
kötötte a jegy és bérletvásárlásokat, ez pedig egyrészt bizonyos okok miatt kirekesztette az addig meglévő szurkolók egy részét, másrészt távol tartott számos új szurkolót.

\section{Anyag és módszer}

Vizsgálatunk egy pilot kutatás, melynek célja, hogy választ találjon arra a kérdésre, hogy miért ilyen alacsony a magyar labdarúgó-mérkőzések iránti nézői érdeklődés. A kérdésre adandó válasz úgy gondoljuk, hogy komplex elemzést igényel, tehát nem elegendő a nyugat-európai vagy észak-amerikai kutatók által létrehozott szurkolói motivációs skála adaptálása, tekintettel arra, hogy ezekben az országokban jellemzően kutatási kérdésként azt fogalmazzák meg, hogy miért járnak az emberek sporteseményekre. Hazánkban, illetve a környezö országokban ezzel szemben nemcsak a szurkolók motivációinak feltárása van szükség, hanem a távolmaradókat visszatartó tényezők elemzésére is, éppen ezért elkészítettünk egy szurkolói, valamint egy távolmaradói kérdőívet is. A kérdőívek az általános demográfiai kérdések mellett, a válaszadók passzív sportfogyasztási szokásait érintette, illetve a kitöltőknek különböző állításokat 1-7-ig terjedő skálán kellett értékelniük az alapján, hogy mennyire értenek egyet az adott állítással és az mennyiben befolyásolja őket a labdarúgó-mérkőzések látogatásában.

A szurkolói kérdőív esetében a klasszikus közgazdasági és szocio-kulturális megközelítést, Trail-James (2001), Fink et al. (2002), Harrolle et al. (2007), KimTrail (2010) és Ulrich-Benkenstein (2010) eredményeit felhasználva egy komplex, belső és külső motivációs tényezőket egyaránt tartalmazó, szurkolói motivációs skálát hoztunk létre, amelyet a következő táblázat mutat be (1. táblázat).

\section{1. táblázat: Komplex szurkolói motivációs skála}

\begin{tabular}{|c|c|}
\hline Belső motivátorok & Külső motivátorok \\
\hline Siker & Látványosság \\
\hline Szurkolói lét & Kimenet bizonytalanság \\
\hline Lokálpatriotizmus & A stadionban uralkodó jó hangulat \\
\hline Csapattal való azonosulás & Játékosok \\
\hline Szórakozás & Létesítmény \\
\hline Közösséghez való tartozás & Hirdetések \\
\hline & Szövetségi intézkedések \\
\hline
\end{tabular}

Forrás: Saját szerkesztés

A távolmaradók elemzéséhez pedig a szurkolói motivációs skálánk mintájára, Kim-Trail (2010), Kassay (2018), Balogh-Bácsné (2019), Balogh et al. (2019) eredményeit felhasználva sportfogyasztástól való tartózkodási skálát hoztunk létre, melynek tényezöit a következő táblázatban foglaltunk össze (2. táblázat). Mind a szurkolói, mind a távolmaradói kérdőív esetében egy-egy faktorhoz 3-3 item tartozott. 
2. táblázat: Komplex sportfogyasztástól való tartózkodási skála

\begin{tabular}{|c|c|}
\hline Belső távolmaradási tényezö & Külső távolmaradási tényező \\
\hline Nem rajongok a sportért & Költségek \\
\hline Sikertelenség & Más szabadidős programok \\
\hline Csapattal való azonosulás hiánya & Más elfoglaltság \\
\hline Nem tudok kivel mérkőzésre menni & Látványosság hiánya \\
\hline Nem érdekel másokat a környezetemben & Élménynélküliség \\
\hline & Média \\
\hline & Szövetségi intézkedések \\
\hline
\end{tabular}

Forrás: Saját szerkesztés

Az adatfelvételre a közösségi média oldalakon történő megosztással, 2019. novemberében került sor, tehát mintavételünk kényelminek tekinthető. Az adatokat az IBM SPSS Statistics 23 program segítségével dolgoztuk fel. Első lépésként a passzív sportfogyasztási szokásokról gyakorisági elemzést végeztünk, majd a skálák reliabilitási vizsgálatára Cronbach-alfa mutatót határoztunk meg. A Cronbach-alfa a legelterjedtebb a skálák megbízhatóságának mérésére (Peterson-Kim, 2013). A Cronbach-alfa esetében nincs egzakt küszöbérték meghatározva, hogy milyen értéktől fogadhatóak el a faktorok, több kutatásban (Takács-Kárász, 2014; Kegye et al. 2018; Paic et al. 2018) a 0,7-et meghaladó értéket tekintik elfogadhatónak, azonban más kutatások (Hinton et al. 2004; Piricz et al. 2013; Szepes et al. 2014) már a 0,6-os értéket meghaladó faktort is elégségesnek tekintik. Végül pedig tekintettel arra, hogy a szurkolói motivációs skálához 14 faktor és 42 item, a tartózkodási skálához pedig 13 faktor és 42 item tartozott, kiemeltük az 5-5 leginkább és legkevésbé befolyásoló állításokat, melynek alapját a számtani átlag adta.

\section{Eredmények}

A kérdőíveinket összesen 481 fö töltötte ki, melyböl 284 fö férfi, 197 fő pedig nő volt. Életkor tekintetében a legtöbben a 18 és 25 éves korosztály képviselték (39,7\%), amelyet a 26-40 év közöttiek (29,9\%), a 41-50 év közöttiek (14,1\%), az 5165 év közöttiek (10,6\%) és a 18 év alattiak $(4,4 \%)$ követtek. A kitöltök legnagyobb része $(40,3 \%)$ diplomával rendelkezik, őket az érettségivel rendelkezők követik $(34,7 \%)$, majd a további sorrend OKJ $(8,5 \%)$, szakmunkásképző $(7,1 \%), 8$ általános $(5,5 \%), \mathrm{PhD}(2,7 \%)$, illetve egyéb $(1,2 \%)$ képzésben szerzett végzettségüek. A szurkolói kérdőívet 232 fö, a távolmaradóit pedig 249 fö töltötte ki.

\subsection{Szurkolói kérdőív eredményei}

A válaszadóink jelentős többsége, $71,1 \%$-a csak hazai mérkőzésekre jár, legnagyobb részük pedig évente csak 1-2 összecsapásra látogat ki. Az igazán fanatikus szurkolók, akik minden hazai és idegenbeli mérkőzésre elkísérik a csapatukat alig több, mint 5,2\%-ban képviseltetik magukat a mintánkban (2. ábra). 
2. ábra: Milyen rendszerességgel jár labdarúgó-mérkőzésre?

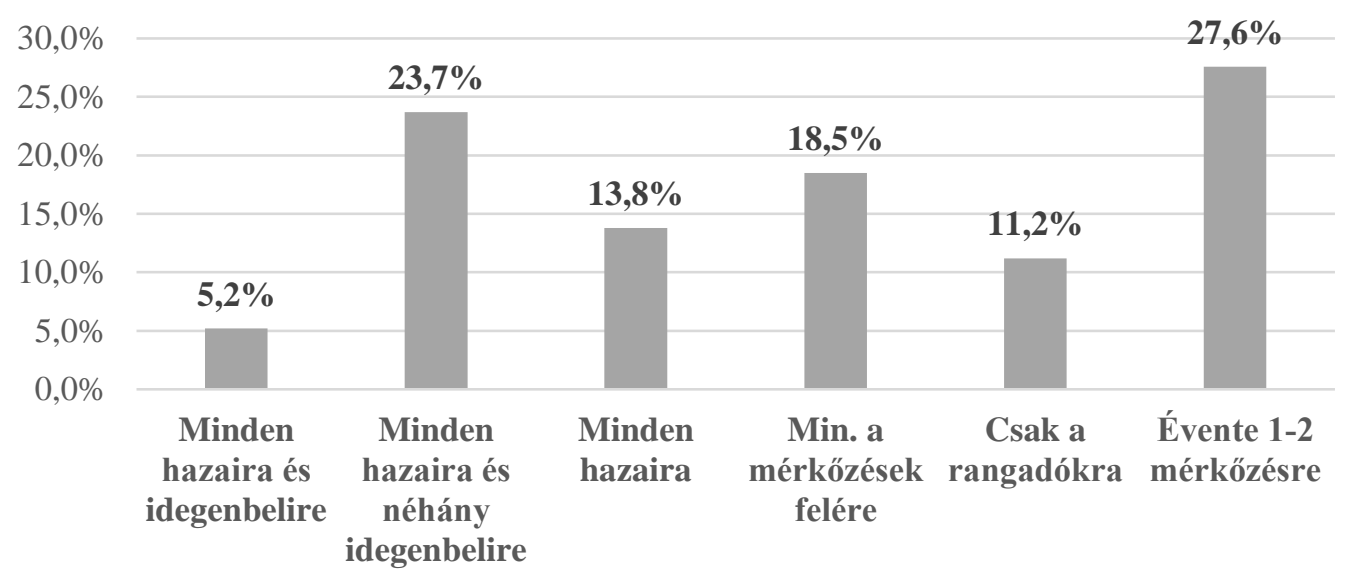

Forrás: saját szerkesztés

Kíváncsiak voltunk arra is, hogy a kitöltők kivel voltak először labdarúgómérkőzésen. A válaszadók legnagyobb része közel 54\%-a az édesapjával vagy az édesanyjával látogatott ki valamelyik stadionba. A szülőket a barátok követik 20,6\%os értékkel, majd a más rokon következik 6,4\%-kal, illetve házastárs/pár haladja még meg az 5\%-os értéket (3. ábra).

\section{3. ábra: Kivel volt elöször labdarúgó-mérkőzésen?}

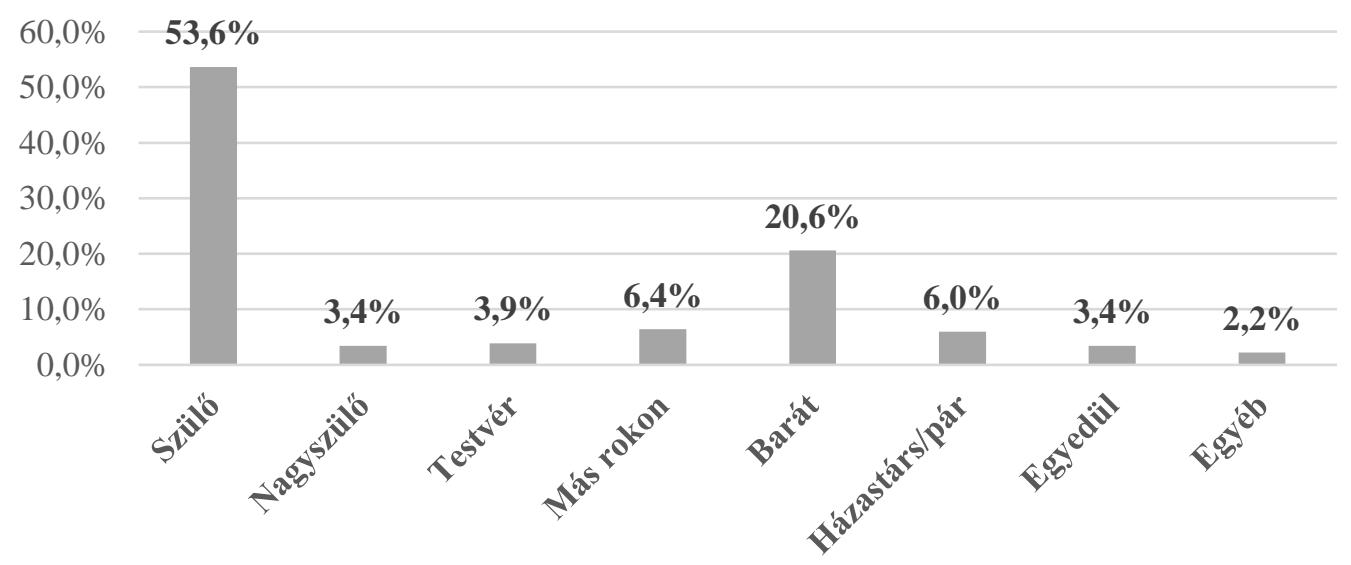

Forrás: Saját szerkesztés

A válaszadók közel 60\%-a gyerekkora óta, több, mint 15\%-a 11-20 éve, 8,2\%-a pedig 5-10 éve jár labdarúgó-mérkőzésekre (4. ábra). Elmondható tehát, hogy a mintánkban szereplők döntő többsége $(83,4 \%)$ több, mint 5 éve jár labdarúgómérkőzésre, amely arra enged következtetni, hogy az új, korszerü és minden igényt kielégítő stadionok nem tudtak érdemben új szurkolókat bevonzani. 


\section{4. ábra: Mióta jár labdarúgó-mérkőzésre?}

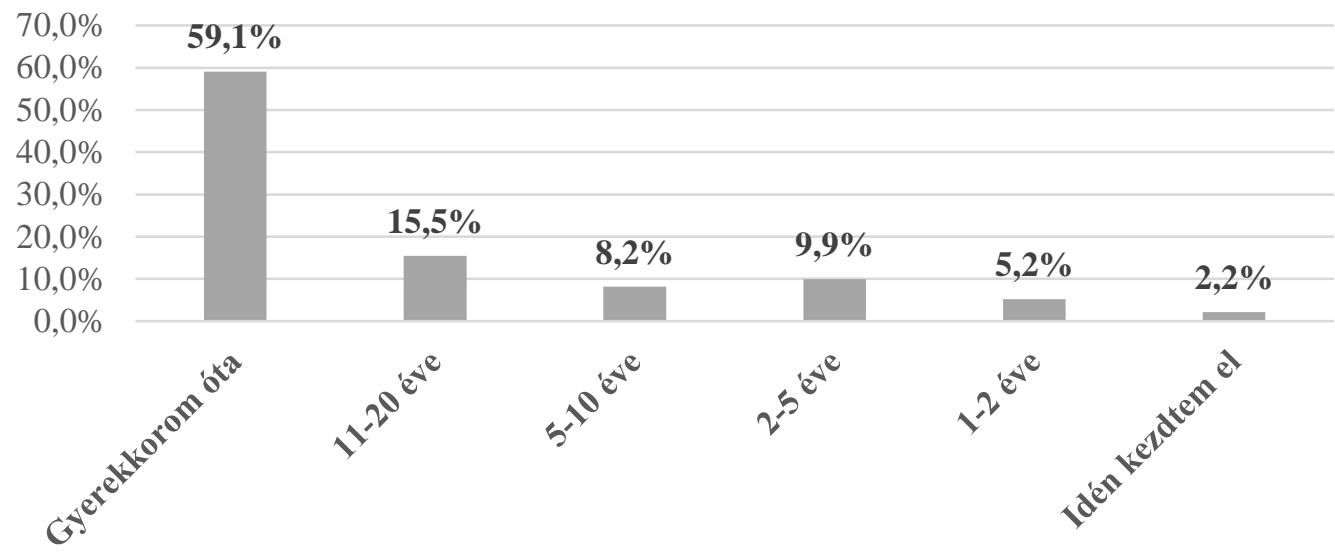

Forrás: Saját szerkesztés

$\mathrm{Az}$ érvényességi vizsgálatunkat Cronbach-alfa számítással végeztük. Amennyiben az anyag és módszer fejezetben már említett, 0,6-os értéket vesszük alapul, akkor két faktor a szurkoló lét, illetve a szövetségi intézkedések nem haladják meg az elfogadható értéket, ha viszont a 0,7-et tekintjük vízválasztónak, akkor e két faktor kiegészül még a látványosság faktorral is (3. táblázat).

3. táblázat: Szurkolói faktorok reliabilitási vizsgálatának eredménye

\begin{tabular}{|c|c|c|c|}
\hline $\begin{array}{c}\text { Belsó motivációs } \\
\text { faktorok }\end{array}$ & $\boldsymbol{\alpha}$ & $\begin{array}{c}\text { Külső motivációs } \\
\text { faktorok }\end{array}$ & $\boldsymbol{\alpha}$ \\
\hline Siker & .86 & Látványosság & $.69^{*}$ \\
\hline Szurkolói lét & $.41^{* *}$ & Kimenet bizonytalansága & .70 \\
\hline Lokálpatriotizmus & .87 & $\begin{array}{c}\text { A stadionban uralkodó jó } \\
\text { hangulat }\end{array}$ & .83 \\
\hline Lojalitás & .97 & A játékosok viselkedése & .87 \\
\hline Csapattal való azonosulás & .96 & Létesítmény & .80 \\
\hline Szórakozás & .83 & Hirdetések & .89 \\
\hline Közösséghez való tartozás & .90 & Szövetségi intézkedések & $.52^{* *}$ \\
\hline \multicolumn{2}{|r}{} & $* *^{* *>0,6 ;}{ }^{*}>0,7$
\end{tabular}

Forrás: Saját szerkesztés

Az állítások közül a legmagasabb átlagot $(6,75)$ a „Sportszerető embernek tartom magam" kapta, megjelenik még a szurkolókat leginkább befolyásoló itemek között a „Szeretem a szép és tetszetős játékot” $(6,62)$, a „Góloknál vagy más pillanatoknál érzett euforikus hangulat" $(6,40)$, majd két lojalitás faktorhoz tartozó állítás következik (4. táblázat). A faktorok közül a válaszadókra a legnagyobb hatással a lojalitás bír. 


\section{4. táblázat: A szurkolókat leginkább befolyásoló itemek}

\begin{tabular}{|l|c|c|}
\hline \multicolumn{1}{|c|}{ Állítások } & Átlag & Szórás \\
\hline 1. Sportszeretö embernek tartom magam & 6,75 & 0,66 \\
\hline 2. Szeretem a szép és tetszetös játékot & 6,62 & 0,84 \\
\hline 3. A góloknál vagy más pillanatoknál érzett euforikus hangulat & 6,40 & 1,14 \\
\hline $\begin{array}{l}\text { 4. Függetlenül attól, hogy a klub hol helyezkedik el a tabellán, én } \\
\text { támogatom a csapatot }\end{array}$ & 6,37 & 1,26 \\
\hline $\begin{array}{l}\text { 5. Attól függetlenül, hogy gyöz vagy veszít a csapat, én továbbra } \\
\text { is támogatom }\end{array}$ & 6,36 & 1,26 \\
\hline
\end{tabular}

Forrás: Saját szerkesztés

A legalacsonyabb átlagot a faktorok közül a média kapta, az öt legkevésbé befolyásoló itemek között mind a három médiához tartozó állítással találkozhatunk. A középértéknél (4) csak egyetlen item, „A bajnokság 12 csapatosra történö átszervezése" kapott alacsonyabb átlagot (5. táblázat).

\section{5. táblázat: A szurkolókat legkevésbé befolyásoló itemek}

\begin{tabular}{|c|c|c|}
\hline Állítások & Átlag & Szórás \\
\hline $\begin{array}{l}\text { 38. A médiában megjelenö hírek a magyar labdarúgásról, } \\
\text { mérközésröl }\end{array}$ & 4,95 & 1,68 \\
\hline 39. Úgy érzem, a város közösségéhez tartozom & 4,91 & 1,83 \\
\hline $\begin{array}{l}\text { 40. Interneten, közösségi médiában megjelenö hirdetések a } \\
\text { mérközésröl }\end{array}$ & 4,85 & 1,80 \\
\hline 41. Plakát, TV-s, rádiós hirdetések a mérközésekröl & 4,35 & 1,86 \\
\hline 42. A bajnokság 12 csapatosra történö átszervezése & 3,57 & 2,10 \\
\hline
\end{tabular}

Forrás: Saját szerkesztés

\subsection{Távolmaradói kérdőív eredményei}

A távolmaradóknak feltettük azt a kérdést, hogy annak ellenére, hogy jelenleg nem járnak labdarúgó-mérkőzésre, voltak-e már, van-e helyszíni tapasztalatuk a magyar labdarúgásról. A távolmaradói kérdőívet kitöltők közel 40\%-a még soha életében nem volt magyar futballmérkőzésen (5. ábra).

Kíváncsiak voltunk arra is, hogy akik kilátogattak már mérkőzésre, utoljára mikor tették meg azt. A válaszadóinknak közel 25\%-a több, mint 10 éve, megközelítőleg 50\%-ának pedig több, mint 5 éve nincs semmilyen helyszíni tapasztalata a magyar futballal kapcsolatban (6. ábra). Ennek alapján kijelenthetö, hogy ezek az emberek még nem jártak az elmúlt években átadott új vagy felújított stadionokban. 


\section{5. ábra: Volt-e már labdarúgó-mérkőzésen}

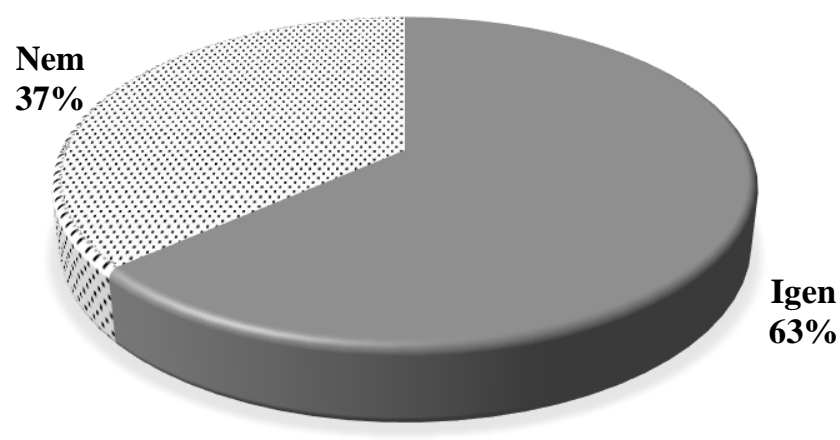

Forrás: Saját szerkesztés

\section{6. ábra: Mikor volt utoljára labdarúgó-mérkőzésen}

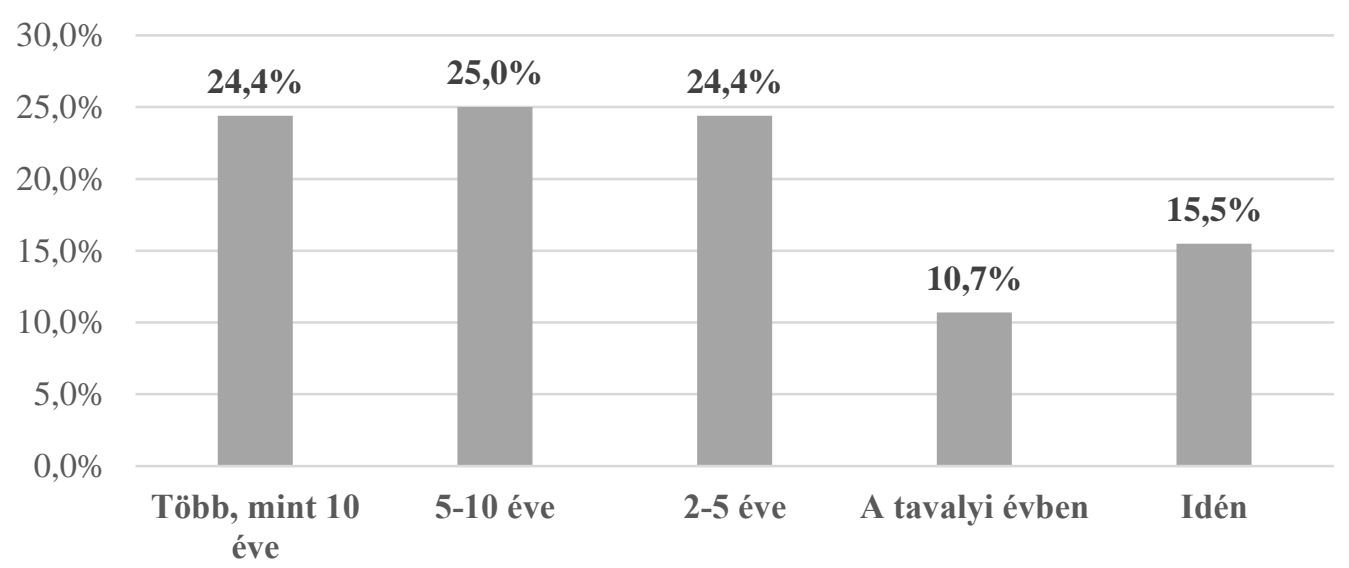

Forrás: Saját szerkesztés

A távolmaradói faktorok reliabilitási vizsgálatánál is a már szurkolói részben említett küszöbértékeket vettük alapul. Ezek alapján elmondható, hogy amennyiben a 0,6-os értéket vesszük alapul, akkor a közvetítések faktor, míg a 0,7-es esetében a közvetítések mellett a sportszövetségi intézkedések faktor állja ki az érvényesség próbáját (6. táblázat).

Az állítások közül a legmagasabb átlagot a „Szabadon elkölthető jövedelmemet inkább másra költöm" kapta, melyet két más szabadidős program item követ, majd a „Nem értek egyet a labdarúgás kiemelt állami támogatásával” következik. Az előzőeken túl az „Alacsony a mérkőzések színvonala” állítás került még be az öt leginkább visszatartó itemek közé. Az eredmények alapján a távolmaradók leginkább azért nem járnak labdarúgó-mérkőzésre, mert más szabadidős programok jobban érdeklik őket (7. táblázat). 
6. táblázat: Távolmaradói faktorok reliabilitási vizsgálatának eredménye

\begin{tabular}{|c|c|c|c|}
\hline $\begin{array}{c}\text { Belső távolmaradási } \\
\text { faktorok }\end{array}$ & $\dot{\alpha}$ & Külső távolmaradási faktorok & $\boldsymbol{\alpha}$ \\
\hline Nem rajongok a sportért & .81 & Költségek & .74 \\
\hline $\begin{array}{c}\text { Nem érdekel másokat a } \\
\text { környezetemben }\end{array}$ & .80 & Más szabadidős program & .75 \\
\hline $\begin{array}{c}\text { Nem tudok kivel } \\
\text { mérkőzésre menni }\end{array}$ & .75 & Más elfoglaltság & .87 \\
\hline Sikertelenség & .94 & Média & .87 \\
\hline $\begin{array}{c}\text { Csapattal való azonosulás } \\
\text { hiánya }\end{array}$ & .78 & Közvetítések & $.44 *$ \\
\hline & & Látványosság hiánya & .78 \\
\hline & & Sportszövetségi intézkedések & $.67 *$ \\
\hline & & Élménynélküliség & .76 \\
\hline & & & $* *>0,6 ; *>0,7$
\end{tabular}

Forrás: Saját szerkesztés

7. táblázat: A távolmaradókat leginkább visszatartó itemek

\begin{tabular}{|l|c|c|}
\multicolumn{1}{|c|}{ Állítások } & Átlag & Szórás \\
\hline 1. A szabadon elkölthetö jövedelmemet inkább másra költöm & 6,14 & 1,61 \\
\hline 2. Inkább elmegyek moziba/színházba/koncertre & 6,10 & 1,58 \\
\hline 3. Inkább elmegyek a barátaimmal szórakozni & 5,98 & 1,61 \\
\hline 4. Nem értek egyet a labdarúgás kiemelt állami támogatásával & 5,85 & 1,90 \\
\hline 5. Alacsony a mérközések szinvonala & 5,67 & 1,78 \\
\hline
\end{tabular}

Forrás: Saját szerkesztés

A távolmaradók esetén is megvizsgáltuk azt, hogy melyek azok az állítások, amik legkevésbé tartják vissza őket a mérkőzések látogatásától. A szurkolókhoz hasonlóan találtunk olyan faktort, amelynek mind a három állítása szerepel az 5 legkevésbé visszatartó itemek között, ez pedig a „Nem tudok kivel mérkőzésre menni”. Emellett megjelenik még a „Médiában megjelenő hírek a csapatról”, illetve az „Inkább megnézem a mérkőzést a TV-ben” állítások is (8. táblázat).

\section{8. táblázat: A távolmaradókat legkevésbé visszatartó itemek}

\begin{tabular}{|l|c|c|}
\hline \multicolumn{1}{|c|}{ Állítások } & Átlag & Szórás \\
\hline 35. A médiában megjelenö hírek a csapatról & 3,26 & 1,96 \\
\hline 36. A párom nem jön el velem & 3,15 & 2,46 \\
\hline 37. Inkább megnézem a mérközést a TV-ben & 3,06 & 2,13 \\
\hline 38. Nem tudok kivel mérközésre menni & 2,67 & 1,96 \\
\hline 39. Nincs olyan barátom, aki eljönne velem & 2,63 & 2,01 \\
\hline
\end{tabular}

Forrás: Saját szerkesztés 


\section{Következtetések}

A korábbi kutatások eredményeit felhasználó szurkolói motivációs skála és sportfogyasztástól való tartózkodási skála faktorainak Cronbach-alfa értéke - egykét kivételtől eltekintve - megfelelt az elvárt küszöbértéknek, így lehetőséget biztosít későbbi vizsgálatok során a faktoranalízis lefolytatására is.

Kutatásunkban sikerült cáfolni azt a közvélekedést, hogy a sikertelenség központi szerepet játszik az alacsony nézői érdeklődésben, hiszen a siker és annak hiánya sem a szurkolók, sem a távolmaradók esetében nem élvez prioritást. A csapattal azonosulni tudó szurkolók nem a siker miatt állnak kedvenc csapatuk mellett, hanem bizonyos idő után hüség alakul ki bennük, melynek következtében ez a lojalitás - gazdasági szempontból - elkötelezett fogyasztókká teszi őket. A labdarúgó-mérkőzésektől távolmaradók sem a sikertelenség vagy éppen az alacsony színvonal miatt nem járnak elsősorban mérkőzésekre, hanem azért, mert szívesebben választanak, valamilyen más szabadidős programot a magyar futball helyett, amely a megváltozott szabadidőeltöltési szokások vizsgálatát teszi szükségessé. A kitöltők közel 40\%-a soha életében nem nézett még meg a helyszínen magyar labdarúgómérkőzést, akik pedig már voltak azoknak többsége több, mint 5 éve. Ez azt jelenti, hogy emberek többségének nincs személyes, helyszíni tapasztalata a magyar labdarúgással kapcsolatban, nem látogattak még el az új stadionokba. A szurkoló válaszadóink többsége jellemzően csak hazai mérkőzésekre látogat ki, az első mérkőzésén gyermekkorában a szüleivel volt. Ennek alapján arra a következtetésre jutottunk, hogy a csapattal való azonosulás, illetve a lojalitás legkönnyebben a gyermekkorban alakulhat ki és nagymértékben függ a szülőktől, ugyanis ezek szerint a szurkolói lét generációkon keresztül öröklődhet.

Az eredmények alapján azt a következtetést vonjuk le, hogy futballkluboknak komoly harcot kell vívniuk a fogyasztók figyelméért, és a versenytársaik nem más sportágak képviselöi, hanem az olyan szereplők, mint például a mozik, koncertek, a színházak vagy más szabadidős programot kínáló szolgáltatók.

\section{Köszönetnyilvánítás}

A publikáció „Az Innovációs és Technológiai Minisztérium ÚNKP-19-3 kódszámú Új Nemzeti Kíválóság Programjának szakmai támogatásával készült."

\section{Irodalomjegyzék}

András K. (2003): Üzleti elemek a sportban. BKÁE, PhD értekezés, Budapest, 2002. 203. p.

András K. (2004): A hivatásos labdarúgás piacai. Vezetéstudomány, 35 (különszám): 40-57.

Bács Z., Kozma G. (2018): Sportlétesítmények a köz szolgálatában: a multifunkcionális stadionok. Magyar Sporttudományi Szemle, 15 (2): 27-34.

Balogh R., Bács Z., Fenyves V., Müller A., Dobay B., Bácsné Bába É. (2019): Are all marketing campaigns in vain if the product is bad? Selye e-studies, 10 (2): 11-19.

Balogh R., Bácsné (2019): Sportszövetségi intézkedések attitüdvizsgálata. Acta Carolus Robertus, 9 (1): 23-33.

Balogh R., Bácsné Bába É. (2019): Az MSSC szurkolói motivációs skála adaptálása egyetemi hallgatók körében. Studia Mundi - Economica, 6 (1): 3-10. 
Bühler A.W. (2005): 'Fans und Fanverhalten im Profifussball: Ein Vergleich zeischen England und Deutschland' in Schewe, G. - Rohlmann, P. (eds) Sportmarketing, Schondorf, Verlag Hofmann. 221-236. p.

Chelladurai P. (1994): Sport management: defining the field. European Journal for Sport Management, 1 (1): 7-21.

Chen Y. C., Lin Y. H., Chiu H. T. (2013) Development and psychometric evaluation of sport stadium atmosphere scale in spectator sport events. European Sport Management Quarterly, 13 (2): 200215.

Clemens M.D., Brush G.J., Collins M.J. (2011): Analysing the professional sport experience: A hierarchical approach. Sport Management Review, 14 (4): 370-388.

Cox A. (2015): Spectator Demand, Uncertainty of Results, and Public Interest: Evidence From the English Premier League. Journal of Sports Economics, 19 (1): 3-30.

Dénes F. (1998): A futball eladásának közgazdasági alapjai. Marketing \& Management, 32 (3): 9-17.

Dobson S. M., Goddard J. A. (1995): The demand for professional league football in England and Wales, 1925-1992. Journal of the Royal Statistical Society, 44 (2): 259-277.

Duke V. (2002): Local Tradition Versus Globalisation: Resistance to the McDonaldisation and Disneyisation of Professional Football in England. Football Studies, 5 (1): 5-23.

Ferguson D.G., Stewart K. G., Jones J.C.H., Le Dressay A. (1991): The Pricing of Sports Events: Do Teams Maximize Profit? The Journal of Industrial Economics, 39 (3): 297-310.

Fink, J.S., Trail G.T., Anderson D.F. (2002): Environmental Factors Associated With Spectator Attendance and Sport Consumption Behavior: Gender and Team Differences. Sport Marketing Quarterly, 11 (1): 8-19.

Forrest D., Simmons, R. (2002): Outcome Uncertainty and Attendance Demand in Sport: the Case of English Soccer. Journal of the Royal Statistical Society, 51 (2): 229-241.

Fort R., Quirk J. (2011): Optimal Competitve Balance in a Season Ticket League. Economic Inquiry, 49 (2): 464-473.

Foster K., Robinson P. (2010) A Critical Analysis of the Motivational Factors that Influence Event Attendance in Family Groups. Event Management, 14 (2): 107-125.

Földesiné Szabó Gy., Gál A., Dóczi T. (2010): Sportszociológia. Semmelweis Egyetem Testnevelés és Sporttudományi Kar, Budapest. 192.

Funk D. C., Filo K., Beaton A.A., Pritchard M. (2009): Measuring the motives of sport event attendance: Bridging the academic-practitioner divide to understanding behavior. Sport Marketing Quarterly, 18 (3): 126-138.

Giddens A. (2008): Szociológia. Osiris Kiadó, Budapest. 833.

Goossens K. (2006): Competitive balance in European football: Comparison by adapting measures: Nataional measure of seasonal imbalance and top 3. Rivista di Diritto ed Economia dello Sport, 2 (2): 77-122.

Gődény N., Biró M., Lenténé Puskás A., Lente L., Müller A. (2018): A fogyasztói szokások és trendek változásának vizsgálata a fitnesz területén. In: Balogh, László (szerk.) Fókuszban az egészség. Debrecen, Magyarország: Debreceni Egyetem Sporttudományi Koordinációs Intézet, 9-18.

Hansen H., Gauthier R. (1989): Factors Affecting Attendance at Professional Sport Events. Journal of Sport Management, 3 (1): 15-32.

Hill B., Green, C. (2000): Repeat Attendance as a Function of Involvement, Loyalty, and the Sportscape Across Three Football Contexts. Sport Management Review, 3 (2): 145-162.

Hinton P.R., McMurray I., Brownlow C. (2004): SPSS Explained 1st Edition. Routledge, London.

Kajos A., Prisztóka Gy., Paic R. (2017): A nézőtéri sportfogyasztás motivációit mérő, magyar nyelvü „SPEED-H” skála validációja és néhány eredménye. Vezetéstudomány, 48 (10): 19-31.

Kassay L. (2012): A sportszórakoztatás nézőért kiált. Marketing \& Menedzsment, 46 (4): 26-35.

Kassay L. (2018): Ismerjük a helyszíni szurkolás nézői attitüdjeit a hazai hivatásos labdarúgásban? Magyar Sporttudományi Szemle, 19 (1): 4-12.

Kassay L., Géczi G. (2016): Competition and Cooperation in European Professional Club Football. Physical Culture and Sport Studies and Research, 69 (1): 22-28. 
Kegye A., Takács Sz., Ries B., Zana Á., Hegedűs K. (2018): A szakmai élet minőségét mérő kérdőív (Professional Quality of Life Scale) magyar változatának validálása. Orvosi Hetilap, 159 (35): 1441-1449

Kim Y.K., Trail, G.T. (2010). Constraints and motivators: A new model to explain consumer behavior. Journal of Sport Management, 24: 190-210.

Lee Y.H., Fort R. (2012): Competitve Balance: Time Series Lessons from the English Premier League. Scottish Journal of Political Economy. 59 (3): 266-282.

Lera Lopez F., Rapún, M. (2011): Determinants of sports participation and attendance: Differences and similarities. International Journal of Sports Marketing and Sponsorship, 12 (2): 167-190.

Madalozzo R., Villar, R.B. (2009): Brazilian football: What brings fans tot he game. Journal of Sports Economics, 10 (6): 639-650.

Madarász T. (2018): Magyar sportsikerekben gazdag egyéni sportágak versenyképességi tényezőinek meghatározása fiatal sportfogyasztók megítélése alapján. Doktori $(\mathrm{PhD})$ értekezés. Debreceni Egyetem Gazdaságtudományi Kar, Debrecen. 174.p.

Müller A. (2009): A legújabb trendek a sportmarketing és menedzsment területén. Magyar Sporttudományi Társaság Sportinnovációs Szakbizottság Évkönyve, 59-63.p.

Müller A., Bíró M., Bodolai M., Hidvégi P., Váczi P., Dávid L., Szántó Á. (2017): A 2016-os fitnesztrendek helye és szerepe a rekreációban. Acta Academiae Pedagogicae Agriensis Nova Series: Sectio Sport, 44: 91-102.

Paic R., Kajos A., Meszler B., Prisztóka Gy. (2018): A magyar nyelvü sportmotivációs skála (HSMS) validációja és eredményei. Magyar Pszichológiai Szemle, 73 (2): 159-182.

Piricz N., Seock-Jin H., Mandják T. (2013) A tranzakciós költségek elmélete és a társadalmi csereelmélet hatásai a bizalomra az ellátási láncban. Vezetéstudomány, 44 (12): 2-13.

Ranc D. (2012): Foreign Players and Football Supporters: The Old Firm, Arsenal, Paris St-Germain. Manchester University Press, Manchester. 256.

Rust R.T, Oliver, R.L. (1994) Service Quality: Insights and Managerial Implications from the Frontier. In: Rust, R.T. and Oliver, R.L., (Eds.) Service Quality: New Directions in Theory and Practice, Sage Publications, Thousand Oaks, 1-19.

Stocker M., Szabó T. (2017): A sportirányítás gazdasági kérdései. Magyar Sporttudományi Szemle, Különszám, 56-78.

Sung H., Mills B.M. (2018): Estimation of game-level attendance in major league soccer: Outcome uncertainty and absolute quality considerations. Sport Management Review, 21 (5): 519-532.

Sutton W.A., McDonald M.A., Milne G.R., Cimperman J. (1997): Creating and fostering fan identification in professional sport. Sport Marketing Quarterly, 6 (1): 15-22.

Székely L., Szabó A. (2017): Magyar Ifjúságkutatás 2016. 99.

Szepes M., Czeglédi E., Urbán R., Horváth K., Balog P. (2014): A szülöi konfliktusok észlelését mérõ skála hazai alkalmazásával szerzett tapasztalatok. Mentálhigiéné és Pszichoszomatika, 15 (2): $139-170$.

Szymanski S. (2003): The Economic Design of Sporting Contests. Journal of Economic Litareture, 41 (4): 1137-1187.

Takács Sz., Kárász J. (2014): Egy egyszerü, újfajta kereszt-validálási eljárás bemutatása. Psychologia Hungarica, 2 (1): 65-77.

Trail G.T., James J. (2001): The motivation scale for sport consumption: assessment of the scale's psychometric properties. Journal of Sport Behavior, 24 (1): 108-127.

Uhrich S., Benkenstein M. (2010): Sport Stadium Atmosphere: Formative and Reflective Indicators or Operationalizing the Construct. Journal of Sport Management, 24: 211-237.

Uhrich S., Koenigstorfer J. (2009) "Effects of atmosphere at major sports events: a perspective from environmental psychology". International Journal of Sports Marketing and Sponsorship, 10 (4): 56-75.

Wafi A.A., Chiu L.K., Kayat K. (2017): Understanding Sport Event Visitors' Motivation and Satisfaction of Small-Scale Sport Event. Journal of Tourism, Hospitality and Environment Management, 2 (3): 13-24. 
Wakefield K.L., Blodgett, J.G. (1996): The effect of the servicescape on customers' behavioral intentions in leisure service settings". Journal of Services Marketing, 10 (6): 45-61.

Wann D. (1995): Preliminary validation of the sport fan motivation. Journal of Sport and Social Issues, 19 (5): 377-396.

Watson J. (2003): Media Communication: An Introduction to Theory and Process. Basingstoke, Palgrave Macmillan. 328.

Yoshida M., James J.D., Cronic J.J. (2013): Sport Event Innovativeness: Conceptualization, Measurement, and Its Impact on Consumer Behavior. Sport Management Review, 16 (1): 68-84. 